\title{
Reconceptualizing Feminist Utopias: Marge Piercy's Woman on the Edge of Time and Margaret Drabble's The Millstone
}

\author{
Bethan Tyler*, Romance Languages
}

\begin{abstract}
Theories of feminist utopia tend to focus on its presence within science/speculative fiction, upholding works like Marge Piercy's 1976 novel Woman on the Edge of Time as exemplars of the genre. Literary critics typically designate this novel's vision of the future, the community of Mattapoisett, as a source of radical, mobilizing inspiration for feminists. I will argue against this reading by attesting that Mattapoisett presents a regressive model of feminism in its failure to permit women the choice of (traditional) maternity and, moreover, does not sufficiently distance itself from that which is condemned in the novel's dystopian present - the stripping of women's reproductive agency. Mattapoisett thus fails to fulfill half of Sally Miller Gearhart's essential criteria for the identification of feminist utopia. By contrast, I argue that Margaret Drabble's 1965 novel, The Millstone, presents a radical vision of maternity, as divorced from patriarchy, that aligns with threads of the feminist movement yet to come at the time of its publication, and that this, under Gearhart's framework, strongly suggests the presence of a feminist utopia. This is striking in that the novel is categorized as a work of realism, rather than science fiction. By revealing the vision of feminism within a speculative fiction novel to be retrograde in comparison with that of a realistic novel, I argue that feminism unyokes realism from the present, thus collapsing boundaries between genres, and making a case for the study of the feminist utopia in realms beyond science fiction.
\end{abstract}

\section{INTRODUCTION}

The feminist movement, like all movements promoting social change, is principally characterized by its forward trajectory: it presents a vision (or rather, visions) for a future in which women and men are "equal." In the 1960 s and 1970s, its prevailing vision was one of sexual freedom(s), with the incipient Sexual Revolution promoting contraception and, when necessary,

*Bethan Tyler is a junior in the Robert D. Clark Honors College. She is pursuing a major in romance languages, with concentrations in Spanish and French. She is originally from the United Kingdom, though she has lived in Portland, Oregon for much of her life. She is passionate about 20th-century literature, especially poetry, written by women in English, Spanish, and French. Outside of class, she writes poetry of her own and volunteers on campus, both as a research assistant with the Modernist Archives Publishing Project and as a DJ at KWVA. Please send correspondence to btyler@uoregon.edu. 
abortion, as tools for diminishing the power of patriarchal, moralizing institutions. The movement touted women's freedom to engage in casual sex, out of wedlock and without pregnancy as a consequence, as a means of patriarchal liberation. In practice, such behavior furthered women's access to the workplace by enabling them to forgo maternal duties, and, moreover, challenged existing norms that equated female sexual license with broader immorality. This iteration of feminism did not account for the entirety of the second-wave feminist movement of which it was a part, though it is the most frequently historicized, perhaps due to its novelty in the context of past feminist movements, which focused more on public enfranchisement of women than on private-sphere liberties. Sexual Revolution-era conceptions of feminism are also often present in novelistic conceptions of feminist utopias, which acclaimed scholar-author Sally Miller Gearhart ${ }^{1}$ characterizes with the following attributes: "contrasts the present with an envisioned idealized society (separated from the present by time or space)," "offers a comprehensive critique of present values/conditions," "sees men or male institutions as a major cause of present social ills," and "presents women not only as at least the equal of men but also as the sole arbiters of their reproductive functions" (Gearhart 296). Given that the tenets of the Sexual Revolution could be described with the three latter traits outlined here, it seems apt that authors of feminist utopian fiction would write from this specific feminist framework.

Sexual Revolution-era values are certainly evident in Marge Piercy's 1976 speculative fiction novel Woman on the Edge of Time, which presents the community of Mattapoisett, situated in the 22nd century, as its utopian vision. Mattapoisett represents a radical departure from modern society in a number of ways, but perhaps its most notable deviances pertain to gender, sexuality, and maternity - precisely the reason why this novel is usually considered a prototypical example of feminist utopia. Piercy depicts a world in which a feminist form of social anarchism prevails, as represented by gender fluidity, the encouragement of total sexual license, pregnancy and childbirth via artificial (external) womb, and a genderless, community-based conception of motherhood that extends only until children reach puberty. These cultural practices are strongly reminiscent of those advocated by Sexual Revolution-affiliated feminists, as they are centered around liberation from patriarchal structures via the estrangement of maternity from womanhood. However, this novel was written about ten years after the peak of the Sexual Revolution (in the 1970s rather than the 1960s), and it seems unusual for a purported utopia to hearken back to past visions of the progressive. It is this surprisingly regressive approach to motherhood that has compelled me to study Woman on the Edge of Time in conjunction with a novel borne of the 1960s, the very time in which the ideals set forth by Piercy flourished.

The Millstone, written by Margaret Drabble in 1965, is not a work of science fiction or speculative fiction, but rather one of realism; yet, like Woman on the Edge of Time, it contends with motherhood in a radical way. Its protagonist, Rosamund, is sexually disinterested - perhaps what we would now term asexual - but chooses to have sexual relations once, resulting in an

\footnotetext{
${ }^{1}$ I have chosen to work with Gearhart's definition for pragmatic reasons - in particular, its clarity, its concision, and its authority. Gearhart both theorizes and writes feminist utopian fiction, which gives her unique credibility in the appraisal of the genre's vital attributes.
} 
unexpected pregnancy. Though she is encouraged to abort the fetus by family members and friends (representative of the same Sexual Revolution-era values that Piercy promotes), Rosamund chooses to have her child, and finds the experience to be edifying and purpose-giving. Drabble positions Rosamund's refusal to conform to the norms of the contemporaneous Sexual Revolution as a matter of radicalism, of choice, freedom, and self-determination. By the end of the novel, Rosamund is continuing her work in academia while maintaining her role as a mother, unfettered by men and surrounded by a community of supportive women. I will argue that the idealized results of Rosamund's choice to become a mother contradict prevailing feminist thought of the era, thus rendering Drabble's conception of feminism progressive, and enabling The Millstone to function as a feminist utopia by Gearhart's definition. Alongside this claim, I will contend that, as Mattapoisett's women are unable to choose to have the experience of maternity, Woman on the Edge of Time fails to fully realize a feminist utopia, as women are not "the sole arbiters of their reproductive functions" (Gearhart 296). By revealing the vision of feminism within a speculative fiction novel to be retrograde in comparison with that of a realistic novel, I argue that feminism unyokes realism from the present, thus encouraging the study of the feminist utopia beyond the realm of speculative fiction and, ultimately, collapsing boundaries between genres.

\section{THE FEMINIST MOVEMENT: 1960-1980}

I will first outline the prevailing threads of feminism in the 1960 s and 1970s, thus establishing the temporal contexts of both The Millstone, which was written amidst the milieu of the Sexual Revolution, and Woman on the Edge of Time, which was published a decade later, when total faith in a hypersexualized vision of feminism was beginning to subside. In their book American Women in the 1960s: Changing the Future, Blanche Linden-Ward and Carol Hurd Green, in part citing historians John D'Emilio and Estelle Freedman, describe the advent of the Sexual Revolution in the 1960 s as follows: "the dominant meaning of sexuality' in America continued to change 'from [...] reproduction within families to [...] emotional intimacy and physical pleasure for individuals.' [...]" (Linden-Ward and Green 369). This change was licensed by the newly widespread availability of contraceptives, which enabled the severance of sex from procreation, thus destabilizing traditional discourse limiting sexual activity to marriage and allowing for sex to become a tool of social deconstruction. Thinking of this nascent conception of sexuality as such a tool positions it within the context of other, contemporaneous movements to dismantle existing systems - for example, the Civil Rights Movement and pacifist activism during the Vietnam War - hence such a name as the "Sexual Revolution." As Linden-Ward and Green note, though, "Some proclaimed a 'sexual revolution,' but it was unclear that it benefitted women as much as men. Women heard that the only way to prove that they were truly 'liberated' was to 'put out,' to be sexually available" (Linden-Ward and Green 369). This is the context within which The Millstone was written, one in which the prevailing image of feminist liberation entailed sexual promiscuity without consequences or guilt, as well as, in some conceptions, the denial of motherhood as an integral part of the female experience (or condemnation of motherhood as symptomatic of patriarchal pressures). Famed early second-wave feminist Simone de Beauvoir - whose thought 
proved a critical touchstone for feminists of the 1960 s - even claimed that "maternity prevents women from finding her own identity" because "the woman is too much of a slave" (Beauvoir, qtd. in Allen 232).

On the contrary, Woman on the Edge of Time was borne of the 1970s, a period of changing attitudes in feminism, framed by a nascent antifeminist movement and shaped by dwindling faith in the Sexual Revolution as a tool of patriarchal destruction. This is the decade in which secondwave feminism fractured, yielding, among other sub-movements, socialist feminism and cultural feminism. ${ }^{2}$ It is thus difficult to characterize the feminism of this decade with any succinct philosophy, though in general it was marked by a radical approach that eschewed the cultural necessity of men. Here I will focus on the emergence of the view that motherhood could form part of a radical resistance movement. In her book Feminism and Motherhood in Western Europe 1890-1970: The Maternal Dilemma, Ann Taylor Allen writes,

Some decided that a radical critique of male supremacy could only come from an oppositional position - a positive female identity. In 1970, the Italian group Rivolta Femminile reclaimed motherhood as a distinctive aspect of that identity: 'The transmission of life, respect for life, awareness of life are intense experiences for woman and values that she claims as her own' (Allen 233).

The perspective expressed here, while equally centered around the liberation of women from societal constructs designed to restrict them, is quite oppositional to that of de Beauvoir, in that it views motherhood not as a symptom of oppression, but as a uniquely feminine experience that could be fostered to empower women.

The advent of this conception of feminism represented an expanded consciousness as to what constituted radical womanhood - no longer was it purely a matter of sexual license, but of building a distinct feminine identity, and this was to become the defining feature of 1970 feminism. One of the most dominant splinters of the feminist movement during this decade was that which is now called cultural feminism, which "focused on creating a 'women's culture' including art, music, and a variety of woman-run institutions [...] [and aimed to] revalue and reaffirm the female, in contrast to the earliest expressions of women's liberation that rejected the idea that there was anything 'essential' about being a woman"' (Evans 143-144). To reiterate, this philosophy was certainly not held by all 1970s feminists, but instead represents a key faction of post-Sexual Revolution feminist thought, as well as the overall evolution of second-wave feminism beyond a single constraining viewpoint - rather more toward a proliferation of potential feminisms that emphasized the value of individual choice and feminine identity.

\section{WOMAN ON THE EDGE OF TIME}

\footnotetext{
${ }^{2}$ I would recommend Sara M. Evans' monograph Tidal Wave: How Women Changed America at Century's End for a much more detailed survey of feminist movements in the latter half of the 20th century.
} 
Using the brief history of the feminist movement in the 1960 s and 1970 siven above, I assess the traditional reading of Marge Piercy's Woman on the Edge of Time as a novel with a feminist utopian vision, issued by way of the future community of Mattapoisett. I argue that this novel's iteration of feminism is most clearly an outgrowth of 1960s, Sexual Revolution-era feminism that prized women's sexual freedom above all and often eschewed the idea that motherhood is essential to womanhood. In doing so, I claim that this novel takes a regressive perspective that somewhat negates its radical potential, and moreover, calls into question its validity as a presentation of feminist utopia: the inability of women to (choose to) have a traditional maternal experience means that Mattapoisett fails to fulfill Gearhart's fourth characteristic of feminist utopia, "presents women not only as at least the equal of men but also as the sole arbiters of their reproductive functions" (Gearhart 296). At present, there are few, if any, essays arguing that Woman on the Edge of Time does not truly present a feminist utopia - most essays argue that it presents a radical mode of resistance against patriarchal systems, as does Vara Neverow's essay "The Politics of Incorporation and Embodiment: Woman on the Edge of Time and He, She and It as Feminist Epistemologies of Resistance.” These essays often treat the novel as a model for feminist resistance for its readers. Many, like M. Keith Booker's "Woman on the Edge of a Genre: The Feminist Dystopias of Marge Piercy," render Piercy's modern United States as a sort of feminist dystopia, compared to which Mattapoisett certainly looks utopian, but takes the utopia itself for granted, without dissecting the ways in which it is and isn't feminist.

Piercy's 20th-century, New Yorker protagonist, Connie, certainly lives in a dystopian world, if we are to characterize dystopia as the opposite of utopia - a world in which, in the words of John Stuart Mill, "what they appear to favour is too bad to be practicable" (Oxford English Dictionary). This is a world in which Connie's agency is totally stripped from her, most notably in her capacity as a woman: her daughter is taken from her by Child Protective Services, and she is held in a mental hospital against her will due to her brother's insistence that she is mentally ill. Perhaps the most striking example of Connie's lack of autonomy comes in a scene in which she is subjected to brain surgery, without consenting to it. Piercy writes, "First Dr. Redding drilled on her skull [...] she could feel the pressure, she could feel the bone giving way, she could hear the drill entering. Then she saw them take up a needle to insert something [...] [into] her penetrated brain" (Piercy 281). As Anna Gilarek points out in her essay "Marginalization of 'the Other': Gender Discrimination in Dystopian Visions by Feminist Science Fiction Authors," this scene is awfully reminiscent of rape in its language of penetration: "This mental and medical rape is one of many references to this manner of domination in the text. In fact, rape can be seen as a "prevalent metaphor to describe society's violent manipulation of those it considers marginal"' (Gilarek 227). Gilarek notes that Piercy's version of the contemporary United States is more broadly rife with violation of the female body by drawing parallels between this scene and others in the novel that portray Connie's experiences with domestic abuse and involuntary hysterectomy. I agree with this reading of Piercy's literary present, and find it useful in contending that Connie's world is not merely a dystopia, but a feminist dystopia: though Connie is the victim of a number of systems of oppression as an overweight, unemployed, (ostensibly) mentally-ill Chicana woman, it is her womanhood (in the sense of her sexual body) that renders her most helpless to the powers that be, her womanhood that licenses rape as metaphor for more general violation. 
While I concur with the critical consensus that Piercy's depiction of the present is dystopian, and push on this to contend that it is more specifically dystopian from a feminist perspective, I diverge from others by contending that Mattapoisett, the vision of the future which Connie uses as a means of escapism, is not strictly a feminist utopia. Though Mattapoisett is certainly a more idealized world than Woman on the Edge of Time's present, its model of maternity embodies a regressive vision of feminism that leaves women without total reproductive freedom. The most striking example of this model of maternity comes in Chapter 5 of the novel, when Connie is taken on a tour of Mattapoisett's "brooder, where our genetic material is stored. Where the embryos grow" (Piercy 106). Piercy writes, "He pressed a panel and a door slid aside, revealing seven human babies joggling slowly upside down, each in a sac of its own inside a large fluid receptacle. Connie gaped, her stomach also turning upside down. All in a sluggish row, babies bobbed. Mother the machine. Like fish in the aquarium at Coney Island" (Piercy 107). This passage summarizes Mattapoisett's mode of pregnancy: all babies gestate within a single artificial womb, rather than within women's individual bodies. Here the estrangement of the female body from reproduction is encapsulated with the quixotic line "Mother the machine," which seems to imply that mothering is merely a matter of mechanics, of unfeeling creation, of input and output (though, given the lack of comma in the quotation, this reading is certainly open to interpretation).

There are stark differences between this conception of reproduction and that which was constructed by feminists of the 1970s: in Mattapoisett, women are utterly unable to experience pregnancy and childbirth as formative processes, which negates the importance of maternity as a part of womanhood and, moreover, eliminates freedom of choice. Of note, though, is that Piercy's depiction of the brooder, though it forms part of her utopian vision, is hardly positive. The babies are described as "sluggish" and compared to "fish in the aquarium at Coney Island," a simile which strips the babies of individual identity and belonging. Even Connie, who comes from a world that Piercy portrays as rife with power imbalance and discrimination, is horrified by the sight: "her stomach [...] turn[s] upside down," (Piercy 107) suggesting discomfort. Perhaps this contradiction within the text suggests that, at the time of writing, Piercy believed that escaping the power imbalances of traditional family structure might entail some aspects that women would not initially be comfortable with, though it certainly seems that she changed her mind about this later, as in her 2016 introduction to the novel, she writes, "If I had the book to write over again, I would include a group that chose to give birth live" (Piercy ix). Regardless, the exclusive model included in the book is that of the brooder, and this reflects a vision of feminism more in alignment with values of the Sexual Revolution of the 1960 s than with those of separatist feminist groups of the 1970s, as it suggests that womanhood need not include motherhood, particularly when that permits sexual license (which, as a practice, is actively encouraged in Mattapoisett). As such it is evident that Mattapoisett's mode of feminism is one borne of a bygone era, one that had already been implemented and deemed insufficient at the time of the novel's publication. Thus, it hardly offers a radical vision for women's futures. By robbing women of the choice to gestate children traditionally, Mattapoisett not only fails to present contemporary or progressive feminist thought, but also blatantly limits women's powers of self-determination. By this token, Woman on the Edge of Time does not thoroughly "critique [...] present values/conditions," (Gearhart 296) as in 
its purportedly utopian future just as in its dystopian present, women are not "the sole arbiters of their reproductive functions" (Gearhart 296). Though Piercy's utopia does critique a number of aspects of the society in which Connie lived, like consumerism and environmental mismanagement, it fails to adequately address the condition that Piercy most condemns in her literary present. Mattapoisett's women suffer from a form of bodily oppression that may appear more benign - one that certainly is not characterized by metaphors of violent penetration - but which ultimately yields the same effect: the stripping of women's reproductive agency. The novel thus fails to fulfill half of Gearhart's criteria for feminist utopia, and can no longer be considered a paragon of the genre.

\section{THE MILLSTONE}

While Woman on the Edge of Time's model of maternity hearkens back to Sexual Revolutionera feminist philosophies of the 1960s, and, moreover, fails to present a feminist utopia in spite of its aspirations, Margaret Drabble's 1965 novel The Millstone exhibits a model of bodily selfdetermination that did not enter mainstream feminism until the 1970s, which renders the novel a radical feminist framework and, by Gearhart's criteria, a feminist utopia.

The very small handful of articles that focus on The Millstone or Drabble's works alone largely approach the novel from a feminist stance, just as I do here, but many of these contend that The Millstone is not a feminist manual, nor is Rosamund a feminist character. ${ }^{3}$ Both "Fate and Feminism in the Novels of Margaret Drabble" by Marion Vlastos Libby and "Fantasy and Femaleness in Margaret Drabble's The Millstone" by Susan Spitzer fall into this category, arguing alternately that Rosamund is a victim of fate or self-deception, though the latter diverges by taking more of a genre-based approach. Spitzer argues that The Millstone transcends its realist genre in its focus on dreams and fantasies. However, she undercuts this claim of innovation by alleging that Rosamund's fantasies of independence and motherhood prove shallow and immature, and that the theme of self-deception is more prominent than that of self-knowledge. My argument follows the same train of thought as Spitzer's, in claiming that the novel does indeed transcend its genre by presenting an idealized, perhaps fantastical vision of motherhood and womanhood, but diverges from her accusation of infantility or impracticality in attesting that the realization of Rosamund's fantasies is representative of a feminist utopia.

Perhaps prior critics can be forgiven for their hesitation to read Rosamund as a feminist character; after all, her lifestyle hardly appears radical. Rosamund is an upper-middle-class University of Cambridge graduate student, researching sonnets and going through the most fundamentally human of processes, pregnancy and childbirth. However, this novel was written amidst the milieu of the Sexual Revolution, which, as I have established, viewed sexual license as the only valid form of feminist womanhood and, at extremes, conceived of motherhood as a consequence of patriarchal enforcement and thus as a part of the female experience that would

${ }^{3}$ A notable exception is "Feminist Ideology of an Academic Woman in Margaret Drabble's The Millstone" by Sümeyra Buran Yilmaz. 
necessarily be eradicated or at least fundamentally altered in order to attain true equality of the sexes. I argue that, in this context, Rosamund's choice of motherhood is radical, particularly given her self-actualization achieved through the process, and her ability to sustain her academic work alongside her mothering duties.

Rosamund's intentionality - her dedication to and realization of a goal - is critical to this reading of radicalism in that it suggests that she is in fact consciously defying the norms of contemporary feminists, and thus carving out a feminist utopia of her own. However, Marion Vlastos Libby claims that "Rosamund continues her pregnancy not because she consciously refuses to conform to social expectations but because she is unable to make a serious choice about her life" (Libby 181). I wholeheartedly disagree with this claim. Though Rosamund does not fall pregnant by choice, and though, at one point, she even attempts to induce miscarriage, she carries through her pregnancy (and thus her choice to be both mother and academic) with a clear sense of conviction. When Rosamund receives a letter from her sister, Beatrice, expressing disapproval of her decision to pursue the pregnancy and suggesting adoption as an alternative, she finds herself defiant: "it revealed to me the depth of my determination to keep the baby. The determination at this stage cannot have been based, as it later was, on love, for I felt no love and little hope of feeling it: it was rather based on an extraordinary confidence in myself" (Drabble 88-89). Here, Beatrice's opinion is representative of centuries of traditional, family-oriented conceptions of reproduction: unmarried single mothers like Rosamund challenge both church doctrine, which condemns reproduction outside of marriage, and conventional mores, which sustains that two parents are necessary to successfully raise a child. Beatrice's advice is intended to protect Rosamund - both in terms of reputation and career - thus Rosamund's resolve to defy her is a conscious choice to defy long-standing social norms.

It is important to add that Rosamund does not merely defy traditional mores, but moreover, the prevailing mode of 1960 s feminism, which viewed contraception and abortion as critical tools for prolonging women's careers and asserting bodily independence. Such a perspective is evident in Drabble's portrayal of Lydia, Rosamund's friend and fellow academic, who sought out an abortion on the grounds that she "was determined not to have [a child]," (Drabble 71) and, as such, demonstrated total control over her own reproduction. However, the ostensibly radical school of thought to which she subscribes aligns in uncomfortable ways with the viewpoint espoused by Beatrice, as both prescribe one-size-fits-all treatments for unmarried single mothers: adoption or abortion. Though mainstream feminists of the 1960s sought to promote bodily independence via access to safe, legal abortions, they failed to recognize the pursuit of pregnancy as a feminist choice, thus, ironically, limiting reproductive independence. By actively choosing to continue her pregnancy while maintaining her career, Rosamund resists both traditional and purportedly progressive schools of thought about motherhood, and asserts true independence over her body and mind.

The result of Rosamund's abject defiance is an idealized world, separate from men, grounded in love between women, and notable for its successful balance between single motherhood and academia, a duality that incarnates a rejection of the patriarchy. Rosamund's child is a daughter, Octavia, whom she raises without a father, in the apartment that she shares with Lydia. Though 
at the beginning of the novel Rosamund is simultaneously dating two men and then has sex with a third (George, Octavia's biological father), by its end, there are no men in her life, save from an absentee brother and father - and this dearth seems quite intentional on Drabble's behalf. Rosamund's relationships with men are performative, in that she feels she must date and have sex in order to hide what she imagines as "a scarlet letter embroidered upon [her] bosom, [...] but the A stood for Abstinence, not for Adultery," (Drabble 21) and thus restrictive, merely symptomatic of societal dictates rather than representative of her own free will. On the contrary, Rosamund's relationship with her daughter is natural and actively freeing. Drabble writes, "[Octavia's] great wide blue eyes looked at me with seeming recognition, and what I felt is pointless to try to describe. Love, I suppose one might call it, and the first of my life" (Drabble 114) and later, "It was no longer in me to feel for anyone what I felt for my child; compared with the perplexed fitful illuminations of George, Octavia shone there with a faint, constant and pearly brightness quite strong enough to eclipse any more garish future blaze" (Drabble 191). Here, it is evident that maternal love gives Rosamund a sense of purpose as a woman that she could not find by attempting to abide by feminist mores of the 1960s - though she had "fitful" feelings for George, with whom her sex out of wedlock represents the Sexual Revolution's image of feminine freedom, she is only able to find true love through her experience of maternity, and this discovery gives her a sense of place.

Rosamund's discovery of her identity as a woman via maternity, rather than sexual license, suggests feminist thought of the 1970s, like that presented in the manifesto of Rivolta Femminile, as she finds "the transmission of life" to be an "intense experienc[e] [...] that she claims as her own" (Allen 233). Though it might be argued that maternity is a far more traditional option than sexual license, and hence less radical (and this is certainly the opinion most evident in Sexual Revolution-era feminist thought), Rosamund ultimately rejects George as a father, which implies that she rejects the narrative that the nuclear family is the only valid family, and, more importantly, suggests that she believes that motherhood is possible in an all-female context. Rosamund's choice of single motherhood only serves to compound her radical womanhood, for, as an academic, Rosamund is also redefining a traditionally masculine landscape. Cambridge did not confer undergraduate degrees to female students until 1948, less than two decades before the publication of The Millstone, and Rosamund is pursuing a doctorate. It is this doubly radical identity that I believe positions Rosamund as a feminist in her own right, and her ability to selfactualize despite this radicalism that I believe positions The Millstone's London as a feminist utopia. Gearhart's definition certainly supports this reading. The novel critiques its era's inability to perceive motherhood as a valid feminist choice, draws contrasts between Rosamund's lifestyle and those of other women whose lives typify Sexual Revolution-era ideals, suggests that Rosamund is a happier person when she is not existing in relation to men, and, most importantly, positions women as "the sole arbiters of their reproductive functions:" Rosamund's choice to pursue her pregnancy is an utterly independent decision. In doing so, The Millstone, though not a work of science or speculative fiction, fulfills all of Gearhart's criteria for feminist utopias other than a separation of her idealized society "from the present by time or space" (Gearhart 296). However, Drabble's radical feminist vision unyokes her realistic text from the present, in that it 
heralds prevailing feminist thought of the future, and thus calls into question whether such distance must be explicitly denoted after all.

\section{CONCLUSION}

Theories of feminist utopia tend to focus on their presence within science fiction and speculative fiction, upholding Marge Piercy's Woman on the Edge of Time as a critical exemplar, yet this novel's imagining of the future community of Mattapoisett does not truly present a feminist utopia. Though the novel is feminist, it adheres to a mode of feminism that prevailed during the Sexual Revolution of the 1960s, rather than to a contemporaneous or forward-looking mode, and its adherence to this feminist vision renders it incomplete as a feminist utopia. Mattapoisett fails to permit women the choice of traditional maternity, thus infringing upon their agency as reproductive arbiters, as does the novel's dystopian present, a world rife with the violent abuse of female bodies. As such, Woman on the Edge of Time fails two of Sally Miller Gearhart's criteria for feminist utopia, "offers a comprehensive critique of present values/conditions" and "presents women not only as at least the equal of men but also as the sole arbiters of their reproductive functions" (Gearhart 296).

On the contrary, Margaret Drabble's realistic novel The Millstone presents a radical vision of maternity divorced from patriarchy that aligns with future threads of the feminist movement, and strongly suggests a feminist utopia, despite its categorization as a work of realism, rather than science fiction. Rosamund's discovery of a sense of purpose through her maternal love for Octavia defies the Sexual Revolution's dictate that feminist womanhood could not include motherhood; as a successful career-woman in a fully female community, divorced from any dependence on men, Rosamund is undeniably a feminist, even as her lifestyle alters to accommodate motherly duties. Drabble thus represents a vision of feminism that would not flourish until the 1970s, a decade after The Millstone was published, with the emergence of movements that advocated separatist female communities and privileged motherhood as an integral part of the unique female experience. In its radical imagination of a new version of feminist womanhood, The Millstone unhinges itself from its era and its genre, and fulfills the spirit of Gearhart's four criteria for a feminist utopia that Woman on the Edge of Time fails to fully bring to fruition. The realization that the vision of feminism within a speculative fiction novel is retrograde in comparison to that within a realistic novel encourages the search for and study of the feminist utopia in genres beyond just science and speculative fiction. Drabble's situation of a feminist utopia within her own time period in The Millstone moreover makes evident that this search must not be limited to works that present dramatically futuristic scenarios, but must rather include works of all temporal focuses, as it is evident that feminism is capable of unmooring literature from the present. In light of these revelations, I urge the radical revision of Gearhart's definition of feminist utopia, and thus, the reconceptualization of the feminist utopia itself.

\section{ACKNOWLEDGMENTS}

I would like to thank Dr. Elizabeth Raisanen for her continual guidance and support in my academic journey - in particular, in the development of my skill and passion for literary analysis 
through a feminist lens. This paper was borne of her class on artificial birth in speculative fiction - two topics I cannot say I had taken great interest in prior to the class - thus, I would like to thank her for encouraging me to explore topics beyond my principal academic interests, and for mentoring me through the process of researching, writing, and refining this paper.

\section{BIBLIOGRAPHY}

Allen, Ann Taylor. Feminism and Motherhood in Western Europe 189o-1970: The Maternal Dilemma. Palgrave MacMillan, 2005.

Barrett, Michèle, and Anne Phillips. Destabilizing Theory: Contemporary Feminist Debates. Stanford University Press, 1992.

Booker, M. Keith. "Woman on the Edge of a Genre: The Feminist Dystopias of Marge Piercy." Science Fiction Studies, vol. 21, no. 3, 1994, pp. 337-350, JSTOR, http:// www.jstor.org.libproxy.uoregon.edu/stable/4240370. Accessed 7 May 2018.

Drabble, Margaret. The Millstone. Harcourt Books, 1965.

“Dystopia, n.” OED Online, Oxford University Press, June 2018, www.oed.com/view/Entry/ 58909. Accessed 7 May 2018.

Evans, Sara M. Tidal Wave: How Women Changed America at Century's End. The Free Press, 2003.

Gearhart, Sally Miller. "Future Visions: Today's Politics: Feminist Utopias in Review." Women in Search of Utopia, edited by Ruby Rorhlich and Elaine Baruch, Schocken Books, 1984, pp. 296-309.

Gilarek, Anna. "Marginalization of 'the Other': Gender Discrimination in Dystopian Visions by Feminist Science Fiction Authors." Text Matters, vol. 2, no. 2, 2012, pp. 221-238, https://doi.org/10.2478/v10231-012-0066-3. Accessed 7 May 2018.

Libby, Marion Vlastos. "Fate and Feminism in the Novels of Margaret Drabble." Contemporary Literature, vol. 16, no. 2, 1975, pp. 175-192, JSTOR, http://www.jstor.org/stable/ 1207546. Accessed 7 May 2018.

Linden-Ward, Blanche, and Carol Hurd Green. American Women in the 1960s: Changing the Future. Twayne Publishers, 1993.

McKenna, Erin. The Task of Utopia: A Feminist and Pragmatist Perspective. Rowman \& Littlefield Publishers, Inc. 2001.

Neverow, Vara. "The Politics of Incorporation and Embodiment: Woman on the Edge of Time and He, She and It as Feminist Epistemologies of Resistance.” Utopian Studies, vol. 5, no. 2, 1994, pp. 16-35, JSTOR, www.jstor.org/stable/20719310. Accessed 7 May 2018. 
Piercy, Marge. Woman on the Edge of Time. 1976. Ballantine Books, 2006.

Sargisson, Lucy. Contemporary Feminist Utopianism. Routledge, 1996.

Spitzer, Susan. "Fantasy and Femaleness in Margaret Drabble's The Millstone." NOVEL: A Forum on Fiction, vol. 11, no. 3, 1978, pp. 227-245, JSTOR, http:// www.jstor.org.libproxy.uoregon.edu/stable/1344962. Accessed 7 May 2018.

Yilmaz, Sümeyra Buran. “Feminist Ideology of an Academic Woman in Margaret Drabble’s The

Millstone." Journal of Research in Gender Studies, vol. 4, no. 2, 2014, pp. 495-513, Academic OneFile, http://link.galegroup.com.libproxy.uoregon.edu/apps/doc/ A397454276/AONE?u=s8492775\&sid=AONE\&xid=47a46287. Accessed 7 May 2018. 